\title{
HUBUNGAN DUKUNGAN SOSIAL DENGAN MOTIVASI MELAKUKAN VCT PADA WAITRESS DI BAR AND KARAOKE SAMPURNA DAN SRI REJEKI DESA BUNGKULAN KABUPATEN BULELENG
}

\author{
(The Correlation Between Social Support Relationship with Motivation of Undertake VCT in \\ Waitress at Bar and Karaoke Sampurna and Sri Rejeki Bungkulan Village District Buleleng)
}

\author{
Putu Agus Ariana ${ }^{1}$, Putu Windi Ridayanti ${ }^{2}$ Komang Gde Trisna Purwantara3 \\ Program Studi S1 Keperawatan, Sekolah Tinggi Ilmu Kesehatan Buleleng \\ e-mail: windiridayanti@gmail.com
}

\begin{abstract}
ABSTRAK
Pendahuluan: Waitress merupakan salah satu kelompok yang berisiko tertular HIV/AIDS. Salah satu program pemerintah untuk mencegah penyakit HIV/AIDS adalah Voluntary Counseling and Testing (VCT). Tujuan dari penelitian ini yakni mengetahui hubungan dukungan sosial dengan motivasi melakukan VCT pada waitress di Bar and Karaoke Sampurna dan Sri Rejeki Desa Bungkulan Kabupaten Buleleng. Metode: Desain penelitian yang digunakan adalah korelasional dengan pendekatan cross sectional. Sampel yang digunakan sebanyak 30 responden yang telah dipilih dengan menggunakan teknik total sampling. Subjek dari penelitian ini adalah wanita yang bekerja ditempat hiburan malam seperti waitress di bar and karaoke Sampurna dan Sri Rejeki pada tahun 2018. Hasil: Analisis data dilakukan dengan uji spearman's rho. Hasil penelitian diperoleh koefisien korelasi $=0,734$ dengan $\mathrm{p}=0,000(\mathrm{p}<0,05)$, maka $\mathrm{H}_{0}$ ditolak dan $\mathrm{H}_{\mathrm{a}}$ diterima. Kesimpulan: Berdasarkan uji analisa data dapat disimpulkan ada hubungan positif yang kuat antara dukungan sosial dengan motivasi melakukan VCT di Bar and Karaoke Sampurna dan Sri Rejeki Desa Bungkulan Kabupaten Buleleng. Berdasarkan penelitian ini diharapkan memberikan informasi mengenai adanya VCT yang digunakan untuk mendeteksi penyakit HIV/AIDS.
\end{abstract}

Kata kunci: Dukungan Sosial, Motivasi, Waitress, VCT, HIV/AIDS

\section{ABSTRACT}

Introduction: Waitress were among the groups at risk of contracting HIV/AIDS. One of the government programs to elemated this kind of desease is voluntary counseling and testing (VCT). This research aims to acknowledge the relationship between Social Support Relationship with Motivation of Undertake VCT in Waitress at Bar and Karaoke Sampurna and Sri Rejeki Bungkulan Village District Buleleng. Methods: The desain of this research that was correlation design with an approach of cross sectional. The collection data are used questionnaire with an amount of sample around 30 respondend. Subjects of this study were women who worked in nightclubs as a waitress in Bar and Karaoke Sampurna and Sri Rejeki in 2018. Results: Data was analyzed by spearman's rho. The hypothesis result showed that correlation coefficient $=0,734$ with $p=0,000(p<$ 0,05), meaning $H_{0}$ rejected and $H_{a}$ accepted. Conclutions: Based on data analysis it can be concluded that there is Correlation between Social Support Relationship with Motivation of Undertake VCT in Waitress at Bar and Karaoke Sampurna and Sri Rejeki Bungkulan Village District Buleleng. Based on this study It is suggested to provide information about VCT and HIV prevention resources.

Keyword: Social Support, Motivation, Waitress, VCT,

HIV/AIDS .

\section{PENDAHULUAN}

Perkembangan kasus di dunia tentang Human Immunodeficiency Virus (HIV) dan Acquired Immune Deficiency Syndrome (AIDS) semakin lama semakin mengkhawatirkan dan merupakan isu kesehatan global sampai saat ini. HIV merupakan suatu virus yang menyerang sistem kekebalan tubuh manusia, terutama semua sel yang memiliki penanda CD4+ dipermukaannya seperti makrofag dan limfosit T. AIDS merupakan suatu kondisi (sindrom) imunosupresif yang berkaitan erat dengan berbagai infeksi oportunistik, neoplasma sekunder, serta manifestasi neurologik tertentu akibat virus HIV (Tanto, et al, 2014).

Pertama kali dilaporkan di Indonesia, jumlah kasus HIV cenderung mengalami perubahan. Pada bulan Januari-Maret 2017 di Indonesia kasus HIV mencapai 10.376 orang, 
berdasarkan data yang diperoleh Kementrian Kesehatan RI. Persentase tertinggi terjadi pada kelompok umur 25-49 tahun $(69,6 \%)$, diikuti kelompok umur 20-24 tahun $(17,6 \%)$, dan kelompok umur $\geq 50$ tahun $(6,7 \%)$. Rasio berdasarkan jenis kelamin adalah laki-laki 2:1 perempuan (Kemenkes RI, 2017 II 1, http://www.aidsindonesia.or.id, diperoleh tanggal 26 januari 2018).

Mengambil tempat penelitian di Bar and Karaoke Sampurna dan Sri Rejeki berada di Desa Bungkulan yang termasuk di wilayah kerja Puskesmas Sawan I, belum dapat dipastikan jumlah invidu yang positif terinfeksi virus HIV di tempat penelitian tersebut karena belum ada pemeriksaan kunjungan langsung ke lapangan khusus ke tempat Bar and Karaoke Sampurna dan Sri Rejeki, tetapi pemeriksaan kunjungan langsung ke lapangan pernah dilakukan pada bulan Januari sampai Agustus tahun 2017 dengan keseluruhan waitress yang bekerja di wilayah Desa Bungkulan didapatkan data bahwa dari total 61 waitress yang bersedia dilakukan pemeriksaan darah terdapat 2 orang positif terinfeksi virus HIV. Berdasarkan data terakhir tercatat di Poliklinik VCT dan IMS Puskesmas Sawan I hingga akhir bulan Maret tahun 2018, tercatat di wilayah kerja Puskesmas Sawan I didapatkan temuan kasus HIV-AIDS mencapai 39 orang.

Menurut Marsum (2016), Waiter atau Waitress adalah sebutan untuk seseorang yang menyajikan makanan dan minuman di dalam sebuah restoran atau bar. Ketika seorang waiter atau waitress melayani tamu makan dan minum di sebuah restoran, ia akan menjadi fokus perhatian para tamu. Mereka mengharapkan pelayanan prima ditampilkan sesuai standar perusahaan lewat pramusaji professional. Penampilan seorang pramusaji "bercerita" banyak tentang dirinya, juga tentang tempat kerjanya. Apakah waiter atau waitress memakai seragam kerja atau tidak, dipastikan bahwa penampilannya secara keseluruhan menunjukan dirinya sebagai seorang yang profesional.

Menyadari tingginya jumlah kasus HIVAIDS di Provinsi Bali, khususnya di Kabupaten Buleleng juga tidak lepas dari bagaimana mendeteksi dini adanya virus HIV pada tubuh. Pada hasil wawancara yang dilakukan kepada owner dan manager Bar and Karaoke Sampurna dan Sri Rejeki, sangat diperlukan untuk melakukan pemeriksaan kepada waitress yang memiliki perilaku berisiko tertular virus HIV melalui program pemerintah tentang VCT.
Tindakan sukarela melakukan VCT untuk deteksi dini adanya virus HIV dapat dipengaruhi oleh beberapa faktor seperti faktor internal (dari dalam dirinya sendiri), yaitu : motivasi. Setiap tindakan yang dilakukan manusia selalu dimulai dengan motivasi yang merupakan serangkaian energi yang mendorong seseorang untuk bangkit melakukan suatu hal untuk mencapai tujuan yang telah ditetapkan. Pencapaian tujuan tersebut dipengaruhi kuat lemahnya motivasi yang dimiliki sehingga akan mempengaruhi hasil yang didapatkan (Sarwono, 2016).

Dukungan untuk melakukan VCT dapat juga diperoleh berupa dukungan sosial, yang dimana pengertian dari dukungan sosial merupakan ketersediaan sumber daya yang dapat memberikan rasa kenyamanan dan psikologi yang diperoleh lewat interaksi bahwa individu tersebut dicintai, diperhatikan, dihargai, oleh orang lain dan ia merupakan bagian anggota dalam suatu kelompok yang berdasarkan kepentingan bersama (Setyoadi \& Triyanto, 2012). Dukungan sosial sangat diperlukan terutama pada pasien HIV yang kondisinya sudah sangat parah. Pemberi dukungan sosial meliputi orang tua, anak, sanak keluarga, teman, tim kesehatan, konselor, dan pasangan (suami/istri) (Nursalam \& Ninuk, 2007, dalam Pratama, 2017).

Berdasarkan hasil studi pendahuluan yang dilakukan oleh peneliti pada tanggal 21 Februari 2018 di Bar and Karaoke Sampurna dan Sri Rejeki yang terdapat di Desa Bungkulan Kabupaten Buleleng, jumlah waitress keseluruhan di 2 lokasi Bar and Karaoke yang tersebut ada 30 waitress dengan usia bekisar antara 18-36 tahun.

Adapun waitress di Bar and Karaoke Sampurna dan Sri Rejeki yang sudah pernah melakukan VCT, karena memiliki motivasi yang baik melakukan VCT disebabkan mendapatkan dukungan dari teman-teman sesama waitress dan orang-orang sekitar di tempat kerjanya. Penulis berasumsi bahwa waitress yang tidak melakukan VCT karena kurang mendapatkan dukungan dari temanteman sesama waitress dan orang di sekitar tempat kerjanya berdampak pada motivasi yang kurang baik dalam melakukan VCT.

Dari uraian tersebut, maka peneliti tertarik untuk melakukan penelitian "Hubungan Dukungan Sosial Dengan Motivasi Melakukan VCT Pada Waitress di Bar and Karaoke Sampurna dan Sri Rejeki Desa Bungkulan Kabupaten Buleleng". 


\section{METODE PENELITIAN}

Penelitian ini merupakan jenis penelitian kuantitatif yang menggunakan metode

penelitian non-eksperimental dengan pendekatan cross sectional yaitu jenis

penelitian yang menekankan waktu pengukuran/observasi data variabel independen dan dependen dinilai hanya satu kali pada satu saat (Nursalam, 2015). Penelitian ini dilaksanakan pada tanggal 9-22 Juni 2018 di Bar and Karaoke Sampurna dan Sri Rejeki Desa Bungkulan Kabupaten Buleleng. Populasi dalam penelitian adalah subjek (misalnya manusia; klien) yang memenuhi kriteria yang telah ditetapkan (Nursalam, 2015). Populasi dalam penelitian ini adalah seluruh waitress di Bar and Karaoke Sampurna dan Sri Rejeki Desa Bungkulan Kabupaten Buleleng sejumlah 30 orang. Pengumpulan data dalam penelitian ini menggunakan kuisioner dukungan sosial dan motivasi melakukan VCT. Analisa data dengan menggunakan uji spearman's rho.

\section{HASIL PENELITIAN PEMBAHASAN}

DAN

Penelitian ini menggunakan 30 sampel di Bar and Karaoke Sampurna dan Sri Rejeki Desa Bungkulan Kabupaten Buleleng dengan karakteristik responden yang meliputi umur, pendidikan, status, lamanya tinggal di Bali.

Tabel 1 Distribusi Frekuensi Responden Berdasarkan Umur di Bar and Karaoke Sampurna dan Sri Rejeki Desa Bungkulan Kabupaten Buleleng

\begin{tabular}{c}
\hline Variabel N Mean Min Max \\
\hline Umur 30 21,6 18 36 Berdasarkan tabel 1, \\
\hline dapat diketahui dapat
\end{tabular}

diketahui bahwa dari 30 responden, rata-rata memiliki umur 26,13.

Tabel 2 Distribusi Frekuensi Responden Berdasarkan Pendidikan di Bar and Karaoke Sampurna dan Sri Rejeki Desa Bungkulan Kabupaten Buleleng

\begin{tabular}{ccc}
\hline $\begin{array}{c}\text { Karakteristik } \\
\text { Pendidikan }\end{array}$ & $\begin{array}{c}\text { Frekuensi } \\
(\mathbf{n})\end{array}$ & $\begin{array}{c}\text { Persentase } \\
(\mathbf{\%})\end{array}$ \\
\hline SD & 6 & 20 \\
SMP/SLTA & 9 & 30 \\
SMA/SMK & 15 & 50 \\
\hline Total & 30 & 100 \\
\hline Berdasarkan tabel 2, dapat diketahui \\
bahwa dari 30 responden, sebagian besar \\
adalah dengan pendidikan SMK/SMA \\
sebanyak 15 responden (50\%)
\end{tabular}

Tabel 3 Distribusi Frekuensi Responden Berdasarkan Status Perkawinan di Bar and Karaoke Sampurna dan Sri Rejeki Desa Bungkulan Kabupaten Buleleng

\begin{tabular}{ccc}
\hline $\begin{array}{c}\text { Karakteristik } \\
\text { Status }\end{array}$ & $\begin{array}{c}\text { Frekuensi } \\
(\mathbf{n})\end{array}$ & $\begin{array}{c}\text { Persentase } \\
(\mathbf{\%})\end{array}$ \\
\hline Belum Kawin & 11 & $36,7 \%$ \\
Kawin & 3 & $10 \%$ \\
Janda & 16 & $53,3 \%$ \\
\hline Total & 30 & $100 \%$ \\
\hline
\end{tabular}

Berdasarkan tabel 3, dapat diketahui bahwa dari 30 responden, sebagian besar adalah dengan status perkawinan janda sebanyak 16 responden $(53,3 \%)$

Tabel 4 Distribusi Frekuensi Responden Berdasarkan Lamanya tinggal di Bali pada waitress di Bar and Karaoke Sampurna dan Sri Rejeki Desa Bungkulan Kabupaten Buleleng

\begin{tabular}{|c|c|c|c|c|}
\hline Variabel & $\mathbf{N}$ & Mean & Min & Max \\
\hline $\begin{array}{l}\text { Lamanya } \\
\text { tinggal di }\end{array}$ & 30 & 10,7 & 1 & 30 \\
\hline
\end{tabular}

Berdasarkan tabel 4, dapat diketahui bahwa dari 30 responden rata-rata lama tinggal di Bali adalah 10,7 bulan

Tabel 5 Data Hasil Penelitian Variabel Dukungan Sosial

\begin{tabular}{lcc}
\hline Dukungan Sosial & $\begin{array}{c}\text { Frekuensi } \\
(\mathbf{n})\end{array}$ & $\begin{array}{c}\text { Persentase } \\
(\%)\end{array}$ \\
\hline $\begin{array}{l}\text { Dukungan Sosial } \\
\text { Tinggi (25-36) }\end{array}$ & 14 & 46,7 \\
$\begin{array}{l}\text { Dukungan Sosial } \\
\text { Sedang (13-24) }\end{array}$ & 12 & 40 \\
$\begin{array}{l}\text { Dukungan Sosial } \\
\text { Rendah (0-12) }\end{array}$ & 4 & 13,3 \\
\hline \multicolumn{1}{c}{ Total } & 30 & 100 \\
\hline
\end{tabular}

Berdasarkan tabel 5, dapat diketahui bahwa dari 30 responden sebagian besar adalah memiliki dukungan sosial tinggi sebanyak 14 responden $(46,7 \%)$.

Tabel 6 Data Hasil Penelitian Variabel Kecemasan Waitress tentang HIV-AIDS

\begin{tabular}{|c|c|c|}
\hline Kecemasan & $\begin{array}{l}\text { Frekuensi } \\
\text { (n) }\end{array}$ & $\begin{array}{c}\text { Persentase } \\
(\%)\end{array}$ \\
\hline $\begin{array}{ll}\text { Motivasi } & \text { Baik } \\
\text { (skor } T \geq 50) & \end{array}$ & 20 & 66,7 \\
\hline $\begin{array}{l}\text { Motivasi } \quad \text { Kurang } \\
\text { Baik (skor } \mathrm{T} \leq 50 \text { ) }\end{array}$ & 10 & 33,3 \\
\hline Total & 30 & 100 \\
\hline $\begin{array}{l}\text { Berdasarkan tal } \\
\text { bahwa dari } 30 \text { res } \\
\text { adalah memiliki mo } \\
\text { responden }(66,7 \%)\end{array}$ & $\begin{array}{l}\text { el } 6 \text {, da! } \\
\text { ponden, se } \\
\text { tivasi baik }\end{array}$ & $\begin{array}{l}\text { It diketahui } \\
\text { agian besar } \\
\text { ebanyak } 20\end{array}$ \\
\hline
\end{tabular}


Tabel 7 Hasil Analisa Hubungan Antar Variabel Dukungan Sosial dengan Motivasi Melakukan VCT

\section{Sikap * Kecemasan Crosstabulation}

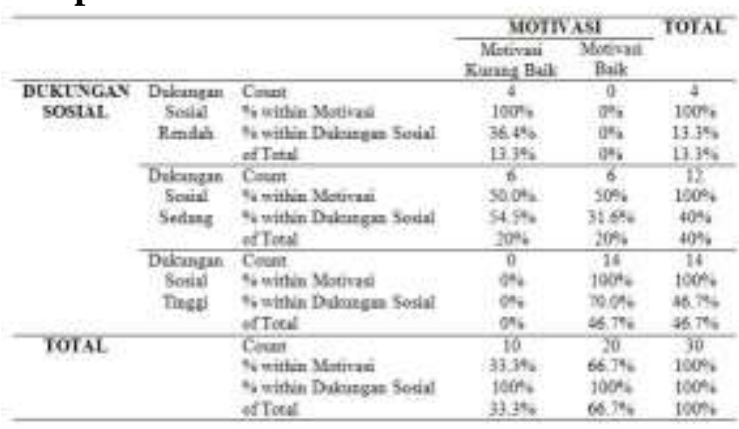

Berdasarkan Tabel 7, dapat diketahui bahwa dari 30 responden yang dilakukan pengukuran dukungan sosial dan motivasi melakukan VCT, sebagian besar adalah memiliki dukungan sosial tinggi dengan motivasi baik sebanyak 14 responden $(46,7 \%)$.

Tabel 8 Hasil Uji Statistik Spearman's rho

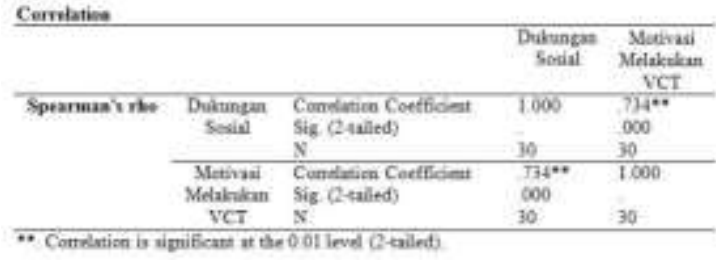

Berdasarkan tabel 8, dapat diketahui bahwa hasil analisa nilai Correlation Coefficient (r) sebesar 0,734 menunjukkan hubungan antara dukungan sosial dengan motivasi melakukan VCT termasuk kuat (diatas 0,5) dan hasil tersebut memiliki nilai positif menunjukkan bahwa semakin tinggi dukungan sosial maka akan semakin baik motivasi melakukan VCT. Dilihat dari hasil $\rho$ $=0,000$, nilai ini lebih kecil dari $\alpha(0,05)$ sehingga $\mathrm{H}_{0}$ ditolak dan $\mathrm{H}_{\mathrm{a}}$ diterima yang berarti ada hubungan dukungan sosial dengan motivasi melakukan VCT di Bar and Karaoke Sampurna dan Sri Rejeki Desa Bungkulan Kabupaten Buleleng.

Dilihat dari karakteristik umur responden bahwa rata-rata memiliki umur 26,13. Artinya, Umur berpengaruh terhadap terbentuknya kemampuan, karena kemampuan yang dimiliki dapat diperoleh melalui pengalaman seharihari yang didukung dengan pengetahuan yang dimiliki dan dukungan dari orang-orang disekitarnya. Didukung oleh penelitian Sarwitiyas Utami (2015) dengan judul "Hubungan Pengetahuan WPS Tentang HIV/AIDS Dengan Motivasi Untuk Mengikuti VCT di Wilayah Kerja Puskesmas Bandung Kabupaten Semarang" menyebutkan data hasil karakteristik dan berdasarkan rekapan sebagian besar berumur 20-35 tahun sejumlah 40 orang $(76,9 \%)$. Hal ini sesuai dengan teori Hulock (1998) semakin cukup umur tingkat kematangan dan kekuatan seseorang akan lebih matang dalam berfikir dan bekerja termasuk untuk melakukan sebuah tindakan seperti melakukan VCT. seseorang yang lebih muda dalam artian umur produktif cenderung memiliki kesadaran yang tinggi untuk melakukan suatu tindakan seperti menjaga kesehatan serta keinginan untuk melakukan tindakan pencegahan dalam hal ini melakukan VCT.

Dilihat dari karakteristik tingkat pendidikan responden, sebagian besar adalah dengan pendidikan SMK/SMA sebanyak 15 responden $(50 \%)$, dan sebagian kecil adalah dengan pendidikan SD sebanyak 6 responden (20\%). Peneliti berasumsi bahwa pendidikan mempengaruhi proses belajar, semakin tinggi pendidikan seseorang semakin mudah orang tersebut untuk menerima informasi dari media maupun dari lingkungan kerja. Di dukung oleh penelitian Sarwitiyas Utami (2015) dengan judul "Hubungan Pengetahuan WPS Tentang HIV/AIDS Dengan Motivasi Untuk Mengikuti VCT di Wilayah Kerja Puskesmas Bandung Kabupaten Semarang" yang menyatakan bahwa baiknya pengetahuan WPS tentang HIV/AIDS juga bisa dipengaruhi oleh pendidikan. Pendidikan diperlukan untuk mendapat informasi misalnya hal-hal yang

menunjang kesehatan sehingga dapat meningkatkan kualitas hidup. Pendidikan dapat mempengaruhi seseorang terutama dalam

memotivasi dalam bertindak, dengan pendidikan tinggi maka seseorang akan cenderung untuk lebih mudah menerima informasi, baik dari orang lain maupun dari media massa maupun dari sesama/rekan waitress. Hasil informasi tersebut yang nantinya dijadikan sebuah dorongan oleh waitress untuk melakukan VCT.

Berdasarkan status perkawinan responden, sebagian besar adalah dengan status perkawinan janda sebanyak 16 responden $(53,3 \%)$ dan sebagian kecil adalah dengan status perkawinan kawin sebanyak 3 responden $(10 \%)$. Peneliti berasumsi bahwa status perkawinan seseorang menentukan dalam memilih suatu pekerjaan seperti menjadi waitress. Didukung oleh penelitian Selfiana Bere Mau (2017) dengan judul "Hubungan Sikap Waitress Tentang HIV-AIDS Dengan Kecemasan Tertular HIV-AIDS di Bar dnd Karaoke Dahlia Dan Sahara Kelurahan Penarukan Kabupaten Buleleng" yang 
menyatakan bahwa profesi yang waitress jalani tidak terlepas dari status sebagian besar para waitress yang janda dan faktor-faktor lainnya yang juga berpengaruh seperti tingkat pendidikan dan lingkungan budaya sekitar. Status perkawinan salah satu dari beberapa faktor yang dapat menentukan dalam seseorang memilih profesi seperti menjadi seorang waitress.

Berdasarkan data lamanya tinggal di Bali, didapatkan bahwa dapat diketahui bahwa dari 30 responden sebagian besar lama tinggal di Bali adalah pada rentang 1 - 12 bulan sebanyak 18 responden (60\%) dan sebagian kecil adalah pada rentang $<1$ bulan sebanyak 4 responden $(13,3 \%)$. Peneliti berasumsi bahwa sebagian besar waitress berasal dari luar pulau Bali. Didukung dengan data dari Sensus Penduduk tahun 2018, dari total penduduk Provinsi Bali (3.890.757 orang), sebanyak 839.373 di antaranya merupakan migran seumur hidup (life time migrants) antar kabupaten/kota. Dapat dikatakan sebagian besar waitress yang bekerja di Bali adalah pendatang.

Berdasarkan penelitian yang dilakukan dapat diketahui bahwa dari 30 responden yang dilakukan pengukuran dukungan sosial dan motivasi melakukan VCT, sebagian besar adalah memiliki dukungan sosial tinggi dengan motivasi baik sebanyak 14 responden $(46,7 \%)$, dan sebagian kecil adalah memiliki dukungan sosial rendah dengan motivasi kurang baik sebanyak 4 responden $(13,3 \%)$. Hasil analisa nilai Correlation Coefficient (r) sebesar 0,734 menunjukkan hubungan antara dukungan sosial dengan motivasi melakukan VCT termasuk kuat (diatas 0,5) dan hasil tersebut memiliki nilai positif menunjukkan bahwa semakin tinggi dukungan sosial maka akan semakin baik motivasi melakukan VCT

begitupun sebaliknya semakin rendah dukungan sosial yang dimiliki maka semakin kurang baik motivasi yang dimiliki. Dilihat dari hasil $\rho=0,000$, nilai ini lebih kecil dari lefel of significiance $(\alpha)$ sebesar 0,05 sehingga $\mathrm{H}_{0}$ ditolak dan $\mathrm{H}_{\mathrm{a}}$ diterima yang berarti ada hubungan dukungan sosial dengan motivasi melakukan VCT di Bar and Karaoke Sampurna dan Sri Rejeki Desa Bungkulan Kabupaten Buleleng.

\section{KESIMPULAN DAN SARAN Simpulan}

Dukungan sosial dari 30 responden diketahui bahwa sebagian besar responden berada dalam rentang dukungan sosial tinggi sebanyak 14 responden memiliki dukungan sosial tinggi (46.7\%) dan 4 responden memiliki dukungan sosial rendah (13,3\%). Motivasi melakukan VCT dari 30 responden diketahui bahwa sebagian besar responden memiliki motivasi baik sebanyak 20 responden $(66,7 \%)$ dan 10 responden memiliki motivasi kurang baik $(33,3 \%)$. Terdapat hubungan yang signifikan $p=0,000(p<0,05)$ antara dukungan sosial dengan motivasi melakukan VCT, dengan koefisien korelasi sebesar 0,734 yang artinya ada hubungan positif yang kuat antara dukungan sosial dengan motivasi melakukan VCT, sehingga hipotesis penelitian yang menyatakan ada hubungan dukungan sosial dengan motivasi melakukan VCT pada waitress di Bar and Karaoke Sampurna dan Sri Rejeki Desa Bungkulan Kabupaten Buleleng diterima.

\section{Saran}

Penelitian ini dapat memberikan informasi mengenai adanya VCT yang digunakan untuk mendeteksi penyakit HIV/AIDS. Peneliti mengharapkan agar masyarakat ikut serta ketika petugas kesehatan mengadakan penyuluhan terkait manfaat VCT serta dinasdinas yang terkait di tempat penelitian disarankan menciptakan kegiatan yang positif seperti memberikan penyuluhan dan pelayanan kesehatan serta pendampingan, kerterbukaan dan kejelasan dalam memberikan informasi sehingga dapat membantu subyek untuk lebih memahami bahaya HIV-AIDS.

\section{REFERENSI}

Marsum, H. (2016). Professional WaitrerPramusaji Ahli. Yogyakarta: Andi.

Nursalam. (2015). Metodelogi Penelitian Ilmu Keperawatan. Jakarta: Salemba Medika.

Ditjen Kemenkes RI. (2017). Laporan Perkembangan HIV/AIDS \& Penyakit

Menular Seksual (PMS) Triwulan I. Tersedia

http://www.aidsindonesia.or.id, 26 januari 2018.

Sarwono, S. W. (2016). Pengantar Psikologi Umum. Jakarta: Rajawali Pers.

Selfiana, M. (2017). Hubungan Sikap Waitress Tentang HIV-AIDS dengan Kecemasan Tertular HIV-AIDS Di Bar and Karaoke Dahlia dan Sahara Kelurahan Penarukan Kabupaten Buleleng, Skripsi, Buleleng, Sekolah Tinggi Ilmu Kesehatan Buleleng. 
Tanto, C. et al. (2014). Kapita Selekta Kedokteran, Edisi ke-IV. Jakarta: Media Aesculapius.

Utami. S. (2015). Hubungan Pengetahuan WPS Tentang HIV/AIDS Dengan Motivasi Untuk Mengikuti VCT di Wilayah Kerja Puskesmas Bandung Kabupaten Semarang, Jurnal, Semarang, Akademi Kebidanan Ngudi Waluyo Ungaran.

Yuliawati, F. (2009). Studi Kasus Perilaku Wanita Pekerja Seksual Tidak Langsung dalam Pencegahan IMS, HIV dan AIDS di Pub \& Karaoke, Cafe dan Diskotek di Kota Semarang, Tesis, Semarang, Universitas Diponegoro. 